\title{
Tensions in future development of organic production-views of stakeholders on Organic 3.0
}

\author{
Rebecka Milestad (D) • Elin Röös • Tove Stenius • Maria \\ Wivstad
}

Received: 7 May 2020 / Accepted: 20 May 2020 /Published online: 2 June 2020

(C) The Author(s) 2020

\begin{abstract}
This study analysed Swedish stakeholders' views on future developments of organic production and consumption based on Organic 3.0, a strategic initiative by the International Federation of Organic Agriculture Movements (IFOAM). Focus group discussions were carried out with actors representing different parts of the organic value chain in Sweden. These identified a number of tensions, four of which represented an
\end{abstract}

R. Milestad $(\bowtie)$

Department of Sustainable Development, Environmental Sciences and Engineering, Teknikringen 10B, Royal Institute of

Technology - KTH, 10044 Stockholm, Sweden

e-mail: rebecka.milestad@abe.kth.se

R. Milestad · E. Röös · M. Wivstad

SLU Centre for Organic Food and Farming (Epok), Swedish University of Agricultural Sciences, Box 7043, 75007 Uppsala, Sweden

E. Röös

e-mail: elin.roos@slu.se

M. Wivstad

e-mail: maria.wivstad@slu.se

T. Stenius

Unit for Collaboration and Development, Swedish University of Agricultural Science, Box 53, 23053 Alnarp, Sweden

e-mail: tove.stenius@slu.se

E. Röös

Department of Energy and Technology, Swedish University of Agricultural Sciences, Lennart Hjelms väg 9, 75007 Uppsala, Sweden unresolved dichotomy in the way forward for the organic movement and its relevance for organic production in most settings. The first tension was between the drive for increased efficiency to achieve higher yields and an agroecological approach with broader sustainability values. The second concerned availability of plant nutrients in organic agriculture including safe recirculating of nutrients from society. The third tension set new technology against the precautionary principle and the notion of naturalness. The fourth concerned the role of organic as an innovation system; whether organic should be a forerunner, i.e. performing well above average and fostering innovation, or whether organic should be a broader movement including more farmers but then requiring more regulations that may hinder innovation. These tensions will result in important choices on direction for the organic sector as it pursues the Organic 3.0 goal of sustainably feeding a growing population based on farming systems based on organic principles.

Keywords Sweden · Agroecology · Innovation · Naturalness $\cdot$ Nutrient recycling $\cdot$ Organic regulations

\section{Introduction}

In 2015, the International Federation of Organic Agriculture Movements (IFOAM) published a report on the future development of organic agriculture that was intended to prompt broad discussions about where the organic movement should go next in order to remain 
relevant (Arbenz et al. 2016). The report contains an analysis of current challenges in society and in the organic movement, a historical account of the emergence and development of the organic sector, and suggestions on how organic production should develop to accommodate current and future challenges. A point of departure in the report is that sustainability challenges in the world have changed, so organic agriculture must also change. Examples include the urgency of climate change mitigation and adaptation, loss of biodiversity, and depletion of natural resources.

The IFOAM report not only acknowledges the sustainability achievements of organic agriculture to date, including positive effects on human health, soil fertility, and biodiversity, but also lists a number of challenges limiting the ability of the sector to have a major impact on sustainable food provisioning for the future (Arbenz et al. 2016). One of these challenges is limited uptake and spread of organic agriculture (i.e. low rate of conversion to organic and thus low impact due to niche status). Another relates to certification systems, which can be bureaucratic and expensive and unable to prevent all fraud. In addition, the environmental benefits in organic production are often not rewarded by the market or by policy instruments, while organic does not properly deliver on all relevant sustainability dimensions. The average lower yields in organic production are also mentioned as a problem (Arbenz et al. 2016). The lower yields in organic agriculture have been much discussed and in some countries such as Sweden there has long been a focus on increasing organic yields (Röös et al. 2018). The challenge is that a single-minded focus on increased yields may decrease the scope for organic production systems to deliver on other sustainability aspects. Since organic standards set minimum requirements (as opposed to high targets), it is possible to be certified organic and still not fulfil organic principles ${ }^{1}$ (Arbenz et al. 2017).

IFOAM has proposed a new Organic 3.0 framework for the organic sector to deal with these challenges (Arbenz et al. 2016). Its aims are to make organic production a more relevant option for sustainable food provisioning, tackle sustainability challenges, and partner up with like-minded social movements and organisations. Six different features are suggested to accomplish this: (1) a culture of

\footnotetext{
${ }^{1}$ The organic principles as described by IFOAM are health, ecology, fairness and care.
}

innovation, including e.g. not only use of new technologies but also farmers' knowledge; (2) continuous improvement towards best practice, which means e.g. outcome-based standards; (3) diverse ways of ensuring transparent integrity, meaning e.g. introducing participatory guarantee systems; (4) inclusion of wider sustainability interests, including alliances with other sustainability movements and taking part in the sustainability debate; (5) holistic empowerment from farm to final consumer, with the focus on empowering socioeconomically weak farmers and women and design of agroecological systems; and (6) true value and cost accounting, meaning e.g. fair prices throughout the value chain and implementation of the 'polluter pays principle' (Arbenz et al. 2016, 2017). Thus, while Organic 3.0 requires clearly defined minimum standards such as those defined in European Union (EU) regulations, it also requires continuous improvements adapted to local conditions (Arbenz et al. 2017, p. 202). Organic 3.0 opens the way for organic standards to become more flexible. There will still be a need for minimum requirements laid down in government regulations and private standards, but standards will also be able to become 'outcome-based, become broader, and/ or address neglected dimensions of sustainability' (Arbenz et al. 2017). Organic 3.0 also opens the way for third-party certification to be complemented with other forms of certification and for alliances with other movements and organisations with goals similar and/or aligned with those of the organic movement. IFOAM calls on all organic actors to contribute to the work for Organic 3.0 and to put it into action (Arbenz et al. 2016).

An initial step in engagement with Organic 3.0 is to increase awareness of the strategy and set it in different contexts. In Sweden, the Centre for Organic Food and Farming (Epok), based at the Swedish University of Agricultural Sciences, initiated a series of focus group discussions with actors from the organic value chain and knowledge system to discuss what the Organic 3.0 initiative could entail for Sweden. The groups discussed the challenges in the Swedish context and how Organic 3.0 features could be developed in the Swedish organic sector. This paper describes the process, its outcomes, and possible ways ahead for the organic movement. Although the analysis centres on the Swedish context, the themes identified are highly relevant for similar contexts, i.e. for many high-income countries where organic production is established, but remains a niche. 


\section{Material and methods}

In 2016 and in spring 2017, five focus group discussions and two workshops were held with organic actors. Invitations were sent to the major organisations working with organic production in Sweden and relevant actors were brought together to take part in the discussions (Table 1). Each focus group discussion was approximately $1.5 \mathrm{~h}$ long and all were recorded and transcribed. In each group, the challenges for organic farming put forward by IFOAM were discussed and participants were asked to add their own reflections and identify themes connected to these challenges. Four of the focus groups (nos. 4-7) were rather homogenous, comprising officials from relevant authorities, organic farmers, members of the KRAV board, and KRAV employees. One mixed group (no. 1) contained actors from restaurants, public procurement, processing industry, municipal officials, and other stakeholders. The two workshops involved advisors and farmers (no. 2) and researchers (no. 3). The focus groups followed a format of structured discussions around the chosen themes, while the workshops used more diverse methods (smaller group discussions, one-to-one discussions, brainstorming, presentations).

The overall questions discussed during both focus groups and workshops were the following: How does the Organic 3.0 strategy relate to the Swedish context? What challenges and opportunities do participants see for Organic 3.0 in Sweden? and What implications does it have for the Swedish context? The transcribed material from all meetings was analysed thematically, which revealed a number of themes (Table 2).

\section{The Swedish context}

In 2016-2017, when the focus groups' discussions were held, $18 \%$ of farmland in Sweden was organically certified or under organic conversion (Statistics Sweden 2017). Almost $10 \%$ of food sales in 2017 were organic products (Ekoweb 2017). Organic production mainly comprised dairy, egg, and meat production, with around $60 \%$ of organic arable land being dedicated to production of ley and pastures for ruminants (Statistics Sweden 2017). Cereals were produced on another $25 \%$ of organic arable land. Vegetables, legumes, and oilseed crops made up only a very small proportion $(<5 \%$ each) of overall organic production. Most of the organic cereals, oilseeds, and legumes produced were used as animal feed, with almost $90 \%$ of all organic arable land being used for crops for animal feed (Cederberg 2011). Manure was the main source of nutrients $(91 \%$ of N and $87 \%$ of P) (Statistics Sweden 2017). The Swedish food strategy action plan (Gov. Bill 2016/17:104) requires production, consumption, and exports of organic food produced in Sweden to increase. Clear targets have been formulated, aiming for $30 \%$ certified area and $60 \%$ organic foods in public procurement. Market actors, authorities, and research organisations have received public funds to support this.

\section{Results}

The overall response in the focus groups and workshops to the Organic 3.0 initiative was positive and it was welcomed as a way to improve the organic

Table 1 Size, date, and membership of focus groups (FG) and workshops (WS)

\begin{tabular}{llll}
\hline Group no. and type & Types of participants & Number of participants & Date \\
\hline 1, FG & Mixed & 20 & 2 May 2016 \\
2, WS & Agricultural advisors and farmers & 100 , divided into & 21 September 2016 \\
3, WS & Researchers at the Swedish University of Agricultural Sciences & 30 & 2 March 2017 \\
4, FG & Board of KRAV & 10 & 22 March 2017 \\
5, FG & Public agencies, National Food Agency, Board of & 6 & 3 April 2017 \\
& $\quad$ Agriculture, The Swedish Chemicals Agency, & \\
6, FG & Swedish Environmental protection agency & & 5 April 2017 \\
7, FG & KRAV employees & 10 & 6 April 2017 \\
\hline
\end{tabular}

${ }^{\text {a }}$ Private Swedish certification system and brand of organic products, which operates in parallel with the basic certification under EU regulation 
Table 2 List of themes identified in the focus groups and the four selected for analysis in this study

\begin{tabular}{|c|c|}
\hline Themes from focus groups & $\begin{array}{l}\text { Themes } \\
\text { analysed } \\
\text { in this } \\
\text { study }\end{array}$ \\
\hline $\begin{array}{l}\text { Increased efficiency versus an agroecological } \\
\text { approach }\end{array}$ & $\mathrm{x}$ \\
\hline $\begin{array}{l}\text { The plant nutrient question: circular economy and } \\
\text { nutrient supply }\end{array}$ & $\mathrm{x}$ \\
\hline Naturalness versus processed inputs & $\mathrm{x}$ \\
\hline \multicolumn{2}{|l|}{ Fossil-free and climate-friendly agriculture } \\
\hline \multicolumn{2}{|l|}{ Increased organic production through conversion } \\
\hline \multicolumn{2}{|l|}{$\begin{array}{l}\text { Increased domestic production of vegetables, fruits, } \\
\text { cereals, and legumes }\end{array}$} \\
\hline \multicolumn{2}{|l|}{ New and alternative markets for organic products } \\
\hline \multicolumn{2}{|l|}{ Future farmers in organic production } \\
\hline Organic production as an innovation system & $\mathrm{x}$ \\
\hline \multicolumn{2}{|l|}{ The role of EU regulation } \\
\hline \multicolumn{2}{|l|}{ The future of organic certification } \\
\hline $\begin{array}{l}\text { Agri-environmental programmes stimulating } \\
\text { sustainability }\end{array}$ & \\
\hline
\end{tabular}

sector in Sweden. However, organic actors in the focus groups did not believe that improvement could be achieved without conducive policy instruments, or by excluding consumers. However, most actors saw it as their responsibility to keep the discussion going and to contribute relevant knowledge. Several participants pointed out that organic initially emerged as a grassroots movement but then evolved into an initiative that was partly 'hijacked by bureaucrats' and saw Organic 3.0 as an opportunity to revive this initial characteristic.

The major aspects discussed in the focus groups were grouped into 12 themes, as detailed by Stenius et al. (2018). The themes partly overlapped; e.g., the role of the EU regulation was often mentioned in relation to other themes. They also differed in their importance to different organic actors and touched to differing degrees on the issues covered by the Organic 3.0 strategy. The importance of the themes was not ranked by the participants. In the present analysis, we focused on themes that (1) indicated a tension, i.e. an unresolved dichotomy related to the way forward for the organic movement, and (2) are highly relevant for organic production in most other high-income settings. On applying these criteria, four themes emerged (Table 2). In the following sections, we summarise the discussion on these themes by focus group and workshop participants, review the overall implications of the themes, and relate their content to previous literature.

Theme 1: increased efficiency versus an agroecological approach

The Organic 3.0 strategy calls for better alignment of organic production with the principles of organic farming and for all sustainability domains to be encompassed. Focus group and workshop participants discussed the perceived dual development pathways for the organic sector. On the one hand, they mentioned a type of production where the focus is on increased use of resource-efficient and less environmentally damaging agricultural inputs, in order to obtain a more efficient organic production with higher yields. In contrast to this, the need to redesign current agricultural systems based on organic principles and agroecological approaches was discussed. The participants reasoned that there is a general view in the Swedish organic sector that the focus should shift from the current input substitution model towards redesign and application of an agroecological approach. This was perceived to be more in line with organic principles, which is important in the communication with consumers, according to the participants. This development pathway was also considered to be more sustainable in the long term.

An agroecological approach, defined by stakeholders as a more 'unregulated version' of organic agriculture, was also discussed as a counter-movement to the development of detailed regulations and rules in current organic production and as the possible future direction of the organic movement. However, the need to define what an agroecological approach means in practice and in terms of certified production was pointed out:

The difficulty is, of course, that if you start developing towards an agroecological approach, you don't know what it stands for. There needs to be an approach, or some kind of limitation, so that you know what it stands for.

It's often a bit superficial and unspecific. Local conditions and circular systems are important, but 
[agricultural systems] are open systems after all, with inputs. You buy machines, you have labour, and yet we talk about striving towards no inputs. This doesn't really hold. [...] what would the characteristics of the organic be?

The agroecological approach to agriculture was advocated during the researcher workshop. Participants in the workshop argued that the added values of organic production (e.g. higher biodiversity, less pesticide use, higher animal welfare) were more important to focus on than a one-sided focus on yield increases in organic. As these added values are crucial for farmers to obtain higher revenues, researchers believed that it is important not to compromise them in the drive for higher productivity in organic production. However, they argued that efficiency is also important, since inefficiencies can result in greater environmental damage per unit product produced. Researchers called for frameworks and indicators for how different aspects of productivity (in terms of resource use, environmental impacts) can be measured and weighted to facilitate decision-making when goal conflicts occur.

Theme 2: the plant nutrient question: circular systems and nutrient supply

Plant nutrients emerged as a major topic and were discussed from two different, but related, perspectives: (i) the need to circulate more nutrients from society back to agriculture, and the role organic production should and could play in this, and (ii) supply of nutrients in organic production and the foreseen shortage of nutrients if organic production is to expand.

On the first theme, there was consensus that nutrient flows need to become more circular. Generally, there was great openness among participants about using digestate from biogas production in organic production. The digestate currently used in organic production in Sweden originates from slaughterhouse waste, food waste, and manure. There was also a recognition of the need, and the potential, for recycling nutrients in human faeces and urine, but that there are still many obstacles to this. For one, it is not permitted under EU regulation on organic production. Some participants reported a sense of increased interest and a more positive attitude to circular systems in society, which could provide new possibilities for discussing recycling of plant nutrients:
Time is more ripe today. Now we are talking about a circular economy in a smarter, more considerate way.

However, there may be demand conflicts for organic substrates, or as one participant pointed out:

We want to reduce food waste, but then food waste for biogas will also decrease.

The second theme was the shortage of plant nutrients for organic production in Sweden. Currently used sources of nutrients are manure from farm animals (including from conventional farms), different agricultural by-products, and nitrogen-fixing crops in crop rotations, where manure dominates. If organic production were to increase, participants argued that shortage of nutrients would be a limiting factor. It was also mentioned that, as some of the manure used in organic production originates from conventional agriculture, organic production uses resources that are not internal to organic. This was seen as a problem:

Plant nutrient supply is a common issue for all agriculture, since it is connected to the climate issue, and so on [...], but it's a burning issue and it's bothering, well, that organic lives on borrowed resources $[\ldots]$ a lot of development work is needed here.

Innovations in the use of sewage sludge could remedy some of the nutrient shortages in organic production, it was agreed. Mineral fertilisers produced from renewable energy sources and recycled phosphorus were also discussed in an open manner, e.g.:

How to deal with nutrient supply, is it ok to use wind power or solar power to produce mineral nitrogen for our production systems? How to think on issues like that? It may be super smart and I think we should be open to new solutions [...] It concerns the issue of resources locally and regionally, water supply, nutrient supply [...] We need to think holistically and sustainably on natural resources.

Overall, there was an openness to new solutions related to nutrient supply currently not permissible in organic production under EU regulation. However, it was also agreed that nutrient supply to field crops, 
especially nitrogen, contributes to distorted nutrient cycles globally. Therefore, it is important to continue to limit the supply of new nitrogen to organic agricultural systems, it was argued. Researchers claimed that EU regulation were the main obstacle to organic farming developing solutions for circular nutrient systems in society. They also called for more knowledge development on issues such as risks of soil contamination in circular systems.

Theme 3: naturalness versus processed inputs

Organic 3.0 opens the way for the use of technologies about which the current organic movement might be sceptical. The focus groups discussed how and to what degree the precautionary principle, a very important guiding principle in organic production (principle of 'care'), should be implemented. The discussion centred around the concept of 'naturalness' and its relation to new technologies. Many participants found naturalness a problematic concept that was blurry and in opposition to innovations and technologies that could help to develop organic production, e.g.:

These visions on naturalness I feel are limiting. Because, what is naturalness? [...] It's natural to develop, and technology is also natural.

However, there were mixed views on this. Some feared that organic would become a greenwashed version of itself if abandoning naturalness and the precautionary principle as guiding principles. For example, while some participants favoured the use of artificial amino acids in poultry feed (currently not allowed), which would make it possible to remove fishmeal from poultry diets, others found this a step in the wrong direction for organic production:

It's pretty controversial that we would feed our animals with synthetic feeds, I think. It would be nice if we could raise our animals on what we can grow in our own fields, in the local areas, and so on.

The use of treated humane urine was not considered a controversial new technology in the groups. Participants agreed that it is often not a black or white choice but often a complex problem that needs to be solved, which often entails a choice between two imperfect solutions.
This discussion also highlighted the need to communicate with consumers about the choices made in the organic sector:

I do believe that it's important to be able to say what it is, what we allow and why.

However, some participants argued that organic would benefit from being perceived as more modern:

You would rather wish for organic to be coloured by modernity. I think [organic] would gain a lot if associated with that. And we could shake off the knitted socks-green-wave stamp of the 70s.

As an example of a modern technology that organic would benefit from using, mining techniques where phosphorus is extracted from sludge was mentioned by another participant:

That would be super important. In terms of environmental pollution, this is a very clean product, it's circular. To be able to use this in organic production would be a leap forward and I hope that the discussion on naturalness will not limit these possibilities.

Theme 4: organic production as innovation system

Organic 3.0 aims to enhance a culture of innovation in organic production. In this theme, two types of tensions were identified by the participants. First, the tension between organic as a forerunner versus organic as the new mainstream for agricultural production was discussed. This concerned the rationale of organic: should it be pioneering and niche, where few producers qualify due to the high standards and where a large price premium can be obtained, or should the aim be to include as many producers as possible, broadening the scope of organic but also running the risk of lowering the price premium? In the Swedish context, the latter objective is favoured. Thus, the wish among participants was for the organic sector to expand in order to reach the overall aim of making food production as a whole as sustainable as possible. At the same time, however, the participants acknowledged the need for the organic 
sector to be a forerunner in creating a more sustainable food system, pushing the overall agricultural sector towards sustainability. One participant also highlighted the role of environmental labelling in driving policy:

When you consider eco-labelling, it is not just the rules and the benefits you get right there [during production of the labelled product]. Eco-labelling is also a driving force for politics. It is a political instrument, which will also increase the acceptance of raising the bottom standard.

The second tension in theme four concerned that between the organic regulation as a catalyst for innovation and the need for creative minds that work best without restrictions. Some participants argued that regulation brings more innovation, since the restrictions it imposes lead to new ways of doing things; e.g., working with crop rotations and natural enemies to create a different kind of production system instead of using pesticides.

Other participants argued that innovators thrive best if they can steer development and are not constrained by any regulation. Rather, individuals need space and enabling structures in order to come up with innovations, they argued. One conclusion drawn was that regulations can hamper or allow innovations depending on how they are designed. In this context, many participants were critical of the EU regulation.

Researchers identified a broad range of issues in need of more research and knowledge development to support the Organic 3.0 initiative. These included the following: development of robust cropping systems, inclusion of alternatives such as agroforestry and permaculture in research efforts, socio-economic impacts of increased conversion to organic production, new market channels for farmers, new organisational forms of agriculture with the aim of reducing economic risks for farmers, systems for valuing and communicating added value in organic production, user-friendly indicators for sustainability impact with a life-cycle perspective, and evaluation of different policy instruments aimed at increasing sustainability in production.

In conclusion, participants in the focus groups and workshops welcomed the Organic 3.0 initiative and agreed that changes are needed to meet sustainability challenges in the organic sector. Participants were open to new technology and innovation; they also pushed for transparency, consumer trust, and systemic sustainability perspectives. While there was agreement on development paths needed for the organic movement - such as the need to handle the plant nutrient question coupled with recycling nutrients from urban areas - other issues were more complex and different arguments were raised.

\section{Discussion}

One tension identified by the organic actors in the focus groups and workshops was that between the growth of the organic sector and the inclusion of more and deeper visions of sustainability in the organic concept. This relates to the different approaches possible: an input-substitution, highefficiency, high-yield approach versus an agroecological, redesign approach. Most Swedish organic production can be characterised as being of the input substitution type, rather than redesigned. For example, organic dairy farms are often specialist dairy farms producing milk as their main product. They use relatively high volumes of concentrates and the specialist high-yielding breeds (cf. Wallenbeck et al. 2019). Another example is the focus on increased yields in organic production. There are a number of goal conflicts between increased yields and other sustainability aspects (Röös et al. 2018). For example, increased use of nitrogen will not only increase yields but will also risk increased nutrient leakage. Reducing the prevalence of weeds will not only increase yields but will also decrease biodiversity, since some weed flowers sustain pollinators that in turn sustain birds. Thus, for organic production to maintain its added environmental values, these goal conflicts need to be considered when strategies for increased yields are implemented (Röös et al. 2018).

Tittonell (2014) argues that input substitution is a mechanism on the road to system redesign, especially in contexts - such as that in Sweden-where development is driven by consumer demand (ibid.). Input substitution means maintaining the guiding model of the production system, e.g. specialist production based on high levels of inputs, but using different types of inputs used. The next step would be (agro)ecosystem redesign 'to decouple agriculture from fossil fuel energy and to make it compatible with nature conservation' (ibid.). In an opposing vein, Darnhofer et al. (2009) describe input substitution not as a means to an end, but as a move away from sustainability in organic production. This is described as the conventionalisation debate in organic 
agriculture; i.e., the idea that organic has developed from a production system where agroecology is a guiding principle to a system that resembles conventional agriculture, but with substitution of inputs (see e.g. Goldberger 2011). This is echoed in the Organic 3.0 call for more emphasis on agroecology (Arbenz et al. 2016). Swedish organic production is embedded in EU regulation, market-driven and supported by agrienvironmental payments. In this context, it is not (economically) feasible to apply a full redesign approach. Thus, moving from an input substitution model to redesign of the agroecosystem would be a major change. However, there are a few examples of farms attempting to move in that direction within the current setting (e.g. Röös 2017).

Organic crop production is currently dependent on conventional manure for its phosphorus and nitrogen supply (Nowak et al. 2013 cit. Karlsson and Röös 2019), which is a bottleneck for expansion of production (Tittonell 2014). This situation was discussed repeatedly in the focus group and workshops. The organic nutrient supply is dominated by animal manure in Sweden (Statistics Sweden 2017). In a future where, for environmental reasons, diets will have to be based less on animal products (Röös et al. 2017), the availability of conventional manure for use in organic production will decrease. Even at present, organic livestock production systems in Sweden are not net providers of plant nutrients, as the manure produced is needed for cultivation of feed crops (with the possible exception of clover-grass based beef and lamb production). If ruminant livestock systems were redesigned to become grass-fed systems (using clovergrass leys fixing nitrogen), in theory, more manure would be available for crop production for human consumption. However, even in such a system, there would be a need for nitrogen and phosphorus inputs from external sources due to the inevitable losses of nutrients to air and water (through e.g. ammonia and nitrous oxide emissions, nitrate leaching, phosphorus run-off).

In a modelling study on a theoretical organic farming system in the Nordic countries supplying a large population with a complete diet, and with livestock production limited to pastures and leftover streams (e.g. agricultural by-products), Karlsson and Röös (2019) identified problems with nutrient supply. They found that the nutrients needed to support such a cropping system could not be supplied even if all nutrients were recycled back from society including food waste, slaughterhouse waste, and nutrients in human faeces and urine.
Moreover, the use of organic fertilisers is not without trade-offs. In a study investigating nutrients from slaughterhouse waste, toilet waste fractions, digested food waste, and mussels, Spångberg (2014) concluded that none of these sources reduced the environmental impacts (energy use, global warming potential, acidification, and eutrophication) compared with mineral fertilisers (used as reference). It is therefore interesting to note that some Swedish organic actors in the focus groups and workshops were open to the use of mineral nitrogen fertilisers produced using renewable energy (cf. Ahlgren et al. 2008), but with two substantial issues: how to prevent overuse of nitrogen and how to communicate acceptance of mineral fertiliser to consumers.

Making nutrient flows more circular is consistent with the principles of organic production. ${ }^{2}$ Increased use of digestate from crop residues and ley biomass could also increase the availability of plant-available nutrients for organic cropping systems. For example, Råberg et al. (2013) suggest that crops for human consumption, feed crops, and crops for biogas could be produced in different types of integrated stockless cultivation systems in order to meet multifunctional objectives. Another example is a system described by Koppelmäki et al. (2019) in which three organic stockless farms cultivating ley for a biogas plant and a bakery are interconnected to improve nutrient cycling and availability. However, there are technical and economic obstacles to overcome before plant material can be turned into digestate on a large scale (Salomon and Wivstad 2013). Sludge, or any other form of waste products originating from human urine or excrement, is not currently allowed under the EU directive (EU 2018/848). IFOAM does not impose a general ban on such products, but has restrictions to protect land and people from pathogens (IFOAM 2014). Human urine and faeces contain large amounts of nutrients (nitrogen, phosphorus, potassium, etc.) from agriculture that are not recirculated in organic production, and only partly in conventional production (Salomon and Wivstad 2013). The reason for the caution from the organic sector is the risk of contamination with pharmaceutical residues and hormones, plus the additional contamination from industrial wastewater and run-off that is treated in sewage plants. However, source-separated urine from humans contains considerably lower levels of e.g. heavy metals

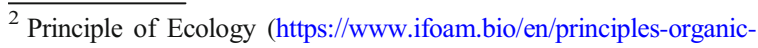
agriculture/principle-ecology)
} 
than sludge (Salomon and Wivstad 2013). It can be a crucial future nutrient resource, as noted by Rahmann et al. (2017): 'on farms without animal integration, solutions for nutrient recycling from urban areas to agriculture will be critical for future sustainability and food security'. Similarly to the view among the focus group participants in this study, 'recent studies have shown that a majority of stakeholders from the organic sector are positive towards increased utilization of human excreta in organic farming' (Løes 2016 cit. Rahmann et al. 2017). Given the objectives on nutrient cycling and efficient use of resources in organic farming (e.g. KRAV 2019), the organic sector could be a driver for using human urine for nutrient supply in agriculture now that solutions which can be integrated into current infrastructure are emerging (Senecal and Vinnerås 2017). However, current legislation is hindering this development.

The discussion about naturalness in organic production can be linked to the precautionary principle, which is central to organic production. There is often confusion about what naturalness means, and thus, communication about it is difficult (Verhoog et al. 2003; Ridder 2007). Verhoog et al. (2003) concluded that naturalness is of moral value in organic production. They pointed out three approaches to naturalness in organic agriculture: the no chemicals approach (where naturalness means using less artificial substances than conventional agriculture), the agro-ecological approach (where naturalness means trying to integrate agricultural activities into nature), and the integrity approach (where naturalness means taking into account the intrinsic value of nature). Depending on the approach taken, different conclusions about the future direction of organic can be reached. This was evident in the focus group and workshops, where participants had different views on e.g. new technologies and artificial feeds. The approach taken depends on a person's worldview, the attitudes in relation to nature (as something 'good' or as something to be controlled?) and the normative views on nature (what we should and should not do with nature) (Verhoog et al. 2003). Expectations of consumers in regard to naturalness were also raised in the focus groups and workshops. Participants were concerned that any actions taken by the organic sector should be easily explainable to consumers. There is evidence that consumers are attracted to foods described as natural (Sandin 2017), while different consumer groups, and other actor groups, attribute different meanings to naturalness (Siipi 2015). It is a challenge to explain complex issues to consumers, which may hamper development if the communication around new technologies is considered too difficult.

Participants in the focus groups had differing views on how an environment supportive of innovations could come about. Some believed that restriction, such as under the organic regulation, offers opportunities for finding new solutions, while other participants believed that the EU regulation are too limiting to set creative minds free. There seems to be some truth in both viewpoints. For example, Pelkmans and Renda (2014) found that regulations can be a stimulus for innovation, while also cautioning that each regulation needs to be assessed for its impact on innovation in context. In a similar vein, Blind (2012) asserts that regulations can have differing impacts on innovativeness. Research shows that organic farmers are often innovators, problem solvers, and experimenters. In Austria, Kummer (2011) found much experimentation going on among organic farmers, who were thus not hampered by the EU regulation in their quest for problem-solving. However, the picture was not clear-cut, as farmers from different regions, with different traditions and geographies, were more or less prone to experimentation and innovation (ibid.). Thus, a number of factors apart from EU regulation influence the degree to which organic farmers innovate. At the same time, there are clearly some issues that cannot be experimented with. The use of human urine for nutrient supply is one of these, which was much discussed in the focus groups. In this case, there is no general prohibition in the organic movement, but EU regulation inhibit development on this issue. Fouilleux and Loconto (2017) see the main objective in an organic standard such as the EU regulation as 'active construction of markets and the facilitation of their expansion'. In other words, innovation and development of solutions for new problems are not major strengths.

\section{Conclusions}

The way forward for the organic sector suggested in Organic 3.0 was generally well-received by Swedish organic actors. However, focus group and workshop participants identified a number of tensions inherent in the strategies laid out in Organic 3.0. The first tension concerned the quest for increased efficiency and higher yields versus an agroecological approach with deeper sustainability values. The second involved 
the availability of plant nutrients in organic agriculture in relation to the possibility to recirculate nutrients from society (in the form of sludge and human urine). The third tension was between new technology, on the one hand, and the precautionary principle and the notion of naturalness, on the other. The fourth tension concerned whether organic should be a forerunner, performing well above the average and thereby fostering innovation, or a broader movement including more farmers, i.e. raising the bottom, but where extent regulations may hinder innovation. These tensions will result in important choices for the organic sector as it pursues the overall goal of the Organic 3.0 initiative, which is to sustainably feed a growing global population based on farming systems adhering to organic principles.

Acknowledgements The authors thank all stakeholders involved for participating in the research process.

Author contributions Röös, Wivstad, and Stenius were jointly responsible for conceptualizing the study, data collection, and writing the report in Swedish. Milestad led work to transform the report into a scientific paper, with contributions from Röös and Wivstad.

Funding information Open access funding provided by Royal Institute of Technology. The SLU Centre for Organic Food and Farming - Epok funded this research.

Open Access This article is licensed under a Creative Commons Attribution 4.0 International License, which permits use, sharing, adaptation, distribution and reproduction in any medium or format, as long as you give appropriate credit to the original author(s) and the source, provide a link to the Creative Commons licence, and indicate if changes were made. The images or other third party material in this article are included in the article's Creative Commons licence, unless indicated otherwise in a credit line to the material. If material is not included in the article's Creative Commons licence and your intended use is not permitted by statutory regulation or exceeds the permitted use, you will need to obtain permission directly from the copyright holder. To view a copy of this licence, visit http://creativecommons.org/licenses/by/4.0/.

\section{References}

Ahlgren S, Baky A, Bernesson S, Nordberg Å, Norén O, Hansson P-A (2008) Ammonium nitrate fertiliser production based on biomass - environmental effects in a life cycle perspective. Bioresour Technol 99:8034-8041. https://doi.org/10.1016/j. biortech.2008.03.041

Arbenz M, Gould D, Stopes C (2016) Organic 3.0 - for truly sustainable farming and consumption, IFOAM Organics International, Bonn and SOAAN, Bonn
Arbenz M, Gould D, Stopes C (2017) ORGANIC 3.0 - the vision of the global organic movement and the need for scientific support. Org Agric 7:199-207

Blind K (2012) The influence of regulations on innovation: a quantitative assessment for OECD countries. Res Policy 41(2):391-400

Cederberg, C (2011) Klimatavtryck av ekologiska jordbruksprodukter. SIK Institutet för livsmedel och bioteknik

Darnhofer I, Lindenthal T, Bartel-Kratochvil R, Zollitsch W (2009) Conventionalisation of organic farming practices: from structural criteria towards an assessment based on organic principles. A review. Agronomy for Sustainable Development DOI 30:67-81. https://doi.org/10.1051 /agro/2009011

Ekoweb (2017) Ekologisk livsmedelsmarknad. Rapport om den ekologiska branschen sammanställd av Ekoweb.nu 26 januari 2017. Ekoweb Sverige. Available at www.ekoweb.nu

Fouilleux E, Loconto A (2017) Voluntary standards, certification, and accreditation in the global organic agriculture field: a tripartite model of techno-politics. Agric Hum Values 34:114. https://doi.org/10.1007/s10460-016-9686-3

Goldberger JR (2011) Conventionalisation, civic engagement, and the sustainability of organic agriculture. J Rural Stud 27:288296

IFOAM (2014) The IFOAM NORMS for organic production and processing. Version 2014. IFOAM-Organics International. Downloaded from: https://www.ifoam.bio/ourwork/how/standards-certification/organic-guaranteesystem/ifoam-norms. Accessed 6 Jan 2020

Karlsson JO, Röös E (2019) Resource-efficient use of land and animals - environmental impacts of food systems based on organic cropping and avoided food-feed competition. Land Use Policy 85:63-72. https://doi.org/10.1016/j. landusepol.2019.03.035

Koppelmäki K, Parviainen T, Virkkunen E, Winquist E, Schulte RPO, Helenius J (2019) Ecological intensification by integrating biogas production into nutrient cycling: modeling the case of agroecological symbiosis. Agric Syst 170:39-48. https://doi.org/10.1016/j.agsy.2018.12.007

KRAV (2019) Standards for KRAV-certified production 2019-20 Edition. Version 2 - updated October 2019. Uppsala. Avialble at: www.krav.se

Kummer, S (2011) Organic farmers' experiments in Austria learning processes and resilience building in farmers' own experimentation activities. Doctoral Thesis, University of Natural Resources and Life Sciences, Vienna, Austria

Løes AK (2016) What does the organic sector think about different phosphorous fertilizers? NORSØK report Vol. 1/No. $3 /$ 2016. Norwegian Centre for Organic Agriculture (NORSØK), Tingvoll, Norway

Nowak B, Nesme T, David C, Pellerin S (2013) To what extent does organic farming rely on nutrient inflows from conventional farming? Environ Res Lett 8(4):044045

Pelkmans J, Renda A (2014) Does EU regulation hinder or stimulate innovation? (November 19, 2014). CEPS special report no. 96. Available at SSRN: https://ssrn. com/abstract $=2528409$

Råberg T, Kreuger E, Björnsson L, Jensen E S (2013) Strategic management of nitrogen within an organic cropping system using digestate from biogas production of recirculated crop 
residues. Organic farming systems as a driver for change. Pp. 109-110 In: Løes A-K, Askegaard M, Langer V, Partanen K, Pehme S, Rasmussen I A, Salomon E, Sørensen P, Ullvén K, Wivstad M (Eds.) Organic farming systems as a driver for change, NJF Report, no. 9 (3)

Rahmann G, Reza Ardakani M, Bàrberi P, Boehm H, Canali S, Chander M, David W, Dengel L, Erisman JW, GalvisMartinez AC, Hamm U, Kahl J, Köpke U, Kühne S, Lee SB, Løes AK, Moos JH, Neuhof D, Nuutila JT, Olowe V, Oppermann R, Rembiałkowska E, Riddle J, Rasmussen IA, Shade J, Sohn SM, Tadesse M, Tashi S, Thatcher A, Uddin N, von Fragstein und Niemsdorff P, Wibe A, Wivstad M, Wenliang W, Zanoli R (2017) Organic agriculture 3.0 is innovation with research. Org Agric 7:169-197

Ridder B (2007) An exploration of the value of naturalness and wild nature. J Agric Environ Ethics 20:195-213. https://doi. org/10.1007/s10806-006-9025-6

Röös E (2017) The sustainable farm - does it exist? Swedish University of Agricultural Sciences, Uppsala, SLU Future Food

Röös E, Bajželj B, Smith P, Patel M, Little D, Garnett T (2017) Greedy or needy? Land use and climate impacts of food in 2050 under different livestock futures. Glob Environ Chang 47:1-12. https://doi.org/10.1016/j.gloenvcha.2017.09.001

Röös E, Mie S, Wivstad M, Salomon E, Johansson B, Gunnarsson S, Wallenbeck A, Hoffmann R, Nilsson U, Sundberg C, Watson C (2018) Risks and opportunities of increasing yields in organic farming. A review. Agronomy for Sustainable Development 38:14. https://doi.org/10.1007/s13593-0180489-3

Salomon E, Wivstad M (2013) Rötrest från biogasanläggningar: återföring av växtnäring i ekologiskt produktion. EPOK Centre of Organic Food \& Farming, Swedish University of Agricultural Sciences, Uppsala
Sandin P (2017) How to label 'Natural'Foods: a matter of complexity. Food Ethics 1:97-107

Senecal J, Vinnerås B (2017) Urea stabilisation and concentration for urine-diverting dry toilets: urine dehydration in ash. Sci Total Environ 586:650-657

Siipi H (2015) Is genetically modified food unnatural? J Agric Environ Ethics 28(5):807-816

Spångberg J (2014) Recycling plant nutrients from waste and byproducts. A life-cycle perspective. Doctoral thesis. Swedish University of Agricultural Sciences, Uppsala 2014. https://pub.epsilon.slu.se/11015/

Statistics Sweden (2017) Ekologisk växtodling 2016. Omställda arealer och arealer under omställning. Statistiska meddelanden JO 13 SM 1707, Jordbruksverket

Stenius T, Wivstad M, Röös E (2018) Nästa steg för ekologiskt lantbruk i Sverige - reflektioner från dialogsamtal. Swedish University of Agricultural Sciences. Centre for Organic Food \& Farming, Uppsala

Tittonell P (2014) Ecological intensification of agriculture - sustainable by nature. Curr Opin Environ Sustain 8:53-61

Verhoog H, Matze M, Lammerts van Bueren E, Baars T (2003) The role of the concept of the natural (naturalness) in organic farming. J Agric Environ Ethics 16:29-49

Wallenbeck A, Rousing T, Sørensen JT, Bieber A, Spengler Neff A, Fuerst-Waltl B, Winckler C, Peiffer C, Steininger F, Simantke C, March S, Brinkmann J, Walczak J, Wójcik P, Ribikauskas V, Wilhelmsson S, Skjerve T, Ivemeyer S (2019) Characteristics of organic dairy major farm types in seven European countries. Org Agric 9:275-291

Publisher's note Springer Nature remains neutral with regard to jurisdictional claims in published maps and institutional affiliations. 